\title{
Regulatory Framework for Space Activities: the Analysis of the Main Regulatory Acts
}

\author{
Olexiy Drozd
}

\author{
Doctor of Law, Associate Professor, National Academy of Internal Affairs \\ (Kyiv, Ukraine) \\ E-mail: alex0674682444@gmail.com \\ https://orcid.org/0000-0002-4514-6594
}

The article is devoted to the legal regulation of space activities in Ukraine. It has been clarified that this type of activities is regulated by a number of laws of Ukraine, decrees of the President of Ukraine, resolutions of the Cabinet of Ministers of Ukraine, acts of the State Space Agency of Ukraine, as well as by multilateral international treaties, international agreements within the CIS, and a large number of bilateral treaties concluded between Ukraine and other States of the world. The basic legal acts of Ukraine concerning implementation of space activities have been analyzed, namely: the Constitution of Ukraine, the Law of Ukraine "On Space Activities", the Law of Ukraine "On Entrepreneurship", the Law of Ukraine "On State Support to Space Activities", "On Approval of the Concept of the National Target Scientific and Technical Space Program of Ukraine for 2018 - 2022”, etc. The main provisions of these acts, as well as the problematic issues that need to be clarified and revised, have been considered. The conclusions indicated that an extensive system of regulatory acts, governing the implementation of space activities, demonstrates the transformation of the space industry into one of the leading sectors of the Ukrainian economy. It has been emphasized that many problems of the space industry still remain unresolved. The mentioned problems have been analyzed and the ways of their solution have been offered.

Keywords: regulatory framework, space activities, space law, regulatory acts

Received: December 27, 2018; accepted: February 01, 2019

Advanced Space Law, Volume 3, 2019: 18-29.

https://doi.org/10.29202/asl/2019/3/2

\section{Intoduction}

Space law is a set of international legal principles and norms governing relations between States and with international organizations in connection with the exploration and use of outer space, which determine international legal status of space, including celestial bodies. It is one of the newest branches of international law.

The formation and development of space law began after the first successes in space exploration. Thus, on October 04, 1957, Soviet scientists launched into space the first artificial

(C) Drozd, Olexiy, 2019 
satellite of the Earth "Sputnik-1". Since then began the countdown of the space age of mankind, which is an example of the influence of scientific and technological revolution on the development of international law.

The interest of all mankind in the progress of the study and use of outer space has given impetus to the adoption in 1967 of Treaty on Principles Governing the Activities of States in the Exploration and Use of Outer Space, including the Moon and Other Celestial Bodies (Independent Institute of International Law, 1997). This treaty defines the most important principles and norms of space law, which include: freedom of research and use of outer space by all States without any discrimination; demilitarization of outer space (partial) and celestial bodies (complete); prohibition of proclamation of State sovereignty on any part of outer space, celestial bodies or their occupation, etc.; preservation of sovereign rights of States on space objects launched by them; international responsibility of the State for national activity in space (regardless of whether it is carried out by governmental or non-governmental institutions), including for the damage caused by space objects; prevention of potentially harmful effects of experiments in space; assisting the spacecraft's crew in case of an accident, etc. In addition to general multilateral treaties, there are also a number of agreements concluded between two or more States on various issues of space activities.

Many achievements of the Soviet Union in space were directly related to Ukraine, its high scientific and technical potential and powerful industrial production. Numerous Ukrainian scientific institutions, design bureaus, and industrial enterprises have been involved in majority of the most important space victories of the USSR.

So, it was therefore quite natural that on February 29, 1992, the National Space Agency of Ukraine (from 2011 - the State Space Agency of Ukraine) was created by the Decree of the President of Ukraine, which provided an opportunity for our country to formulate its own State policy in the area of exploration and use of outer space. In April 1996, the National Space Agency of Ukraine and the National Academy of Sciences of Ukraine established the Space Research Institute. In the same year, the National Center for Space Management and Testing was established, which is engaged in management of space vehicles, control of outer space, reception and processing of special and scientific information.

The space law of Ukraine is regulated by a number of both national and international legal acts of different legal force, which is an indication that our State is a full-fledged space State in the international arena. So let's turn to the consideration of the most important of these acts and define the range of issues that they regulate.

\section{Law of Ukraine On space activities}

The Constitution of Ukraine holds the highest level in the hierarchical system of legal acts, that is, it is the basis for all other legal acts. This means that all regulations must be drafted on the basis of the Constitution of Ukraine and comply with its provisions. The Basic Law determines, among other things, the principles of space activity in Ukraine. Thus, Article 92, part 5 enshrines that exclusively by the laws of Ukraine are defined: the principles of use of natural resources, exclusive (marine) economic zone, continental shelf, development of outer space, organization and operation of power systems, transport and communications.

The main law regulating issues related to the implementation of space activities in Ukraine is the Law "On Space Activities", which was put into effect on November 15, 1997, further amended. According to this Law, the basic principles of space activity in Ukraine are: State regulation; 
State support for the commercialization of space activities and attraction of investments into the space industry of Ukraine; the evolution of development and the consistency in reforming the State policy in the area of exploration and use of outer space; the effective use of scientific and technical potential of Ukraine, the opportunities provided by space activities in the interests of the national economy, science, security of the State and for commercial purposes; promoting international co-operation, preservation and development of existing international ties in the space industry taking into account national interests [Law, 1996].

Space activities are aimed at: promoting socio-economic and scientific progress of the State, increasing the welfare of citizens; participation in solving common problems of mankind; the development of space science and technology, space services and technologies that condition the stable development of the national economy; creation of a powerful export potential of the space industry; provision of access to space, realization of scientific researches of the Earth and outer space; creation and support of the modern information space of the State by the space means; ensuring long-term interests of the State in the sphere of national security and defense; promotion of education; participation in monitoring the implementation of agreements concerning international security, to which Ukraine is a party.

Besides, the special Law defines the principles of the organization of space activities, formulates general requirements for objects of space activities, outlines measures for ensuring safety of space activities, and also defines the place of Ukraine in ensuring security of space activities.

However, as Yulian Drapailo correctly states, the Law of Ukraine "On Space Activities" does not list the directions of space activity, although such a provision is in the relevant laws of many foreign countries. After conducting his own research, the author proposes to allocate the following areas of space activity: 1) scientific space research; 2) creation of space objects and devices and mechanisms necessary for the operation of space objects; 3) launch of space objects; 4) remote sensing of the Earth from outer space; 5) use of space technologies for communication, television and radio broadcasting; 6) use of space technologies for defense purposes and in order to ensure the State's security [Drapailo, 2012].

We draw attention to the fact that the Law "On Space Activities" does not specify a mechanism for compensation for damage caused by the accomplishment of space operations, as it is done in the laws of most European countries. Thus, Article 13 of the French Law Concerning Space Operations [Loi, 2008] determines that the operator shall be solely liable for damages caused to third parties by the space operations which it conducts in the following conditions: 1) he shall be absolutely liable for damages caused on the ground or in airspace; 2) he shall be liable only due to his fault for damages caused elsewhere than on the ground or in airspace.

Article 9 of the Belgian Royal Decree implementing certain provisions of the Law of 17 September 2005 on the activities of launching, flight operations and guidance of space objects enshrines that in the case of damage referred to in article 15, $\$ 2,2$, of the Law and the related assessment procedure, the State and the operator shall determine by mutual agreement the rules to apply to the damage assessment procedure after having consulted the experts designated for that purpose. Failing such an agreement or if the experts have not been designated beforehand by the parties, the latter shall apply the Expertise Rules of the International Chamber of Commerce, provided that these are compatible with this decree [Law, 2005].

We should note, that responsibility in space law is possible both for violation of the norms of international law (international legal responsibility) and for violating of the norms 
of national law (national legal responsibility). Therefore, we believe that the mechanism of compensation for damage caused in the area of space activities must necessarily be prescribed in a special law.

\section{Law of Ukraine "On entrepreneurship"}

According to Article 4 of the Law of Ukraine "On Entrepreneurship" activity related the production and operation of rocket carriers, including space launchers for any purpose, may only be carried out by State-owned enterprises and organizations.

Many experts consider such a provision of the Law unreasonable and which restricts competition, and therefore the Draft Law no. 9219 "On Amending Certain Laws of Ukraine on Facilitating the Development of Space Activities and Involvement of Investments in the Space Industry of Ukraine" was registered in the Verkhovna Rada of Ukraine.

Thus, the Draft Law of Ukraine proposes to make changes to Article 4 of the Law of Ukraine "On Entrepreneurship", which will enable to de-monopolize the space industry and to carry out corresponding economic activity by private enterprises. Besides, in order to maintain effective State control, it is proposed to replace the licensing mechanism of space activities, enshrined in the Law of Ukraine "On Space Activities", with the mechanism of issuing freeof-charge permits for testing and launches of launch vehicles, the launch or providing support for the launch of a spacecraft, the return of the spacecraft or its component parts from the Earth orbit or outer space to Earth, control of the spacecraft.

This change will make it possible to bring the Law of Ukraine "On Space Activities" into conformity with the Law of Ukraine "On Licensing the Types of Economic Activities", which effectively abolished the licensing of space activities. Thus, the adoption of the Draft Law will ensure the development and de-monopolization of space activities, as well as increase the investment attractiveness of the industry and provide effective State control in accordance with the international obligations of Ukraine.

However, according to the relevant publication, the Verkhovna Rada rejected this Bill, since less than the minimum required number of 226 deputies voted for its adoption [Space, 2019].

We hope that the document will still be completed and submitted for reconsideration and approval, since its adoption will create thousands of new jobs and facilitate the development of the production of new samples of rocket carriers and spacecraft.

\section{Law of Ukraine "On state support to space activities"}

The purpose of the adoption of the Law of Ukraine "On State Support to Space Activities" [Law, 2000] is: preservation and further development of the scientific-technical, technological and industrial potential of the space industry as one of the factors of national security; increasing the export potential of the space industry and competitiveness of developments (products) of domestic entities of space activity; creation of economic conditions and provision of guarantees for attraction of investments (including foreign ones) for development of the space industry.

The force of this Law applies to the subjects of space activity, which carry out this activity in accordance with the Law of Ukraine "On Space Activities". The objects of space activity are enterprises, institutions and organizations, including international and foreign ones, which carry out space activities. 


\section{Concept of the National target scientific and technical space program of Ukraine for $2018-2022$}

As space activity contributes to the realization of national interests, enhancement of State defense and national security, innovative development of the national economy, improvement of the quality of life of Ukrainian citizens, on September 5, 2018, the Concept of the National Target Scientific and Technical Space Program of Ukraine for 2018 - 2022 was adopted by the Order of the Cabinet of Ministers of Ukraine no. 629-2018-p. [Concept, 2018].

It should be noted that from 1994 to 2017 four space programs were adopted in Ukraine. None of them were completely fulfilled, as they were $30-35 \%$ funded. And in such important areas as creation of space complexes and providing industrial and technical development at the expense of the State budget, funding was either symbolic or was not provided at all [Prokopchuk, 2019].

As it is stated in the Preamble to the Concept itself, space activities in Ukraine did not become an effective instrument for achievement of the State's geopolitical goals; the provision of independent geospatial data, navigation information and satellite communications are not provided promptly. Besides, the role of space activities in the innovative development of the economy is insufficient. The main reasons for such problems are: limited funding of space activities and insufficient State support for the space industry; loss of markets and the need for import substitution; loss of a part of the ground space infrastructure in the Autonomous Republic of Crimea; long delays with the implementation of structural changes in the space industry; lack of an internal market for space services; new tasks and challenges in the area of national security and defense.

Therefore, the purpose of the Concept is to increase the efficiency of use of space potential for solving urgent tasks of socio-economic, ecological, cultural, informational, scientific and educational development of society, ensuring the realization of State interests in the area of defense and national security through three options for solving the problem.

The first suggests preservation of existing approaches to space activities, minimum financial and political support from the State, and mobilizing insignificant amounts of extra budgetary resources.

The second option involves implementation of space activities on a commercial basis with regulatory function of the State exclusively, the development of only those space technologies that have a high level of commercial attractiveness on the world market.

The third option (optimal) provides for creation of conditions for implementation of State interests at the national and international level and the direct effect of space activities on the State's economy by attracting foreign investment (as a result of business activity) along with comprehensive political, organizational, legislative and financial support by the State.

Despite the fact that the Concept determines the ways for overcoming for each of these problems, significant progress in their solution is not noticeable. According to Anna Bukvich, with reference to the regulation of the relevant relations by the norms of public procurement, the absence of exchange control and preferential tax treatment, as well as clearly defined unified criteria and requirements for the public-private partnership contract, the Government does not have a clear vision of public-private partnership policy and development that complicates the selection of potential projects [Bukvych, 2016].

However, experts hope that, in addition to securing the State's interests at national and international levels and achieving a direct effect on the State's economy from space activities 
by attracting foreign investment (as a result of business activity of enterprises), along with direct financial support from the State, the program of the Concept will increase the level of the State's defense capability and national security by executing the State's order; will deepen mutually beneficial international cooperation, in particular with the European Space Agency.

\section{Regulation on the State space agency of Ukraine}

The State Space Agency of Ukraine provides realization of the State policy in the area of space activity. The main act, which regulates the activity of this specially authorized central executive body of Ukraine is the Regulation on the State Space Agency of Ukraine, approved by the Resolution of the Cabinet of Ministers of Ukraine on May 14, 2015, no. 281 [Regulation, 2015].

In late 1991, after the dissolution of the USSR, Ukraine inherited almost a third of the Soviet rocket and space potential, for which, on February 29, 1992, the National Space Agency of Ukraine was created by the decree of the President of Ukraine. The latter took under its guidance over 30 design bureaus, scientific organizations and institutions, military units and industrial enterprises directly involved in space activities. In 1999, the status of the National Space Agency was changed; more than 20 enterprises and organizations were transferred under its authority. Thereby an independent space industry of the national economy of Ukraine was created.

In 2015, the National Space Agency of Ukraine was transformed into the State Space Agency of Ukraine. The State Space Agency of Ukraine (SSA) is the central executive body which activities are directed and coordinated by the Cabinet of Ministers of Ukraine and which ensures formation and implementation of State policy in the area of space activities and provides support in preparation and implementation of international projects in the area of exploration and use of outer space.

The structure of the SSA includes: the Department of Space Projects, the Office of International Affairs, the Office of Financial and Economic Policy, the Office of Space Industrial Infrastructure, the Office for the Provision of Space Activities. The Collegium and the Scientific and Technical Council were formed in the structure of the SSA to discuss the most important directions of activity and development of the space industry. The SSA is headed by the Chief, who is appointed and dismissed by the Cabinet of Ministers of Ukraine on the proposal of the Prime Minister of Ukraine. The Chief has the first deputy and the deputy, who are appointed and dismissed from their offices by the Cabinet of Ministers of Ukraine in due course. In its activities, the SSA is subordinated to the Government of Ukraine.

The tasks of the SSA are: development of the conceptual foundations of State policy in the area of research and use of outer space for peaceful purposes and in the interests of State security; ensuring organization and development of space activities in Ukraine and under the jurisdiction of Ukraine outside its borders; assistance in improving the defense capability and national security of the State using space means; organization and development of Ukraine's cooperation with other States and international organizations in the space industry.

The SSA develops the National Space Program of Ukraine, as well as other scientific and technical programs and basic research projects and applications, including international ones, in the area of space industry and ensures their implementation. The SSA is the State's general customer of exploration and use of outer space, research activities on design, manufacture and testing of space technologies; it issues licenses to business entities for scientific researches 
related to creation and use of space engineering and technology (besides carrier rockets), development, testing, production and operation of spacecraft and their component parts, terrestrial space infrastructure and its component parts, equipment that is part of the space segment of satellite systems. SSA provides operation, maintenance and improvement of space activities. This body is also responsible for organizing selection of candidates and training astronauts for manned space flights; realization of registration of objects of space activity; organization of development and operation of the Ukrainian Space Equipment Certification System and a number of other functions [Yurydychna, 2002: 532].

In twenty five years of the SSA's existence, five State Space Programs have been implemented that have contributed to the development of space activities, the establishment of international contacts, world space services market entry, the implementation of unique international projects.

During this time the rocket and space industry of Ukraine has been formed; modern legal framework has been prepared for work in the world market and participation in large-scale space projects (which is over 140 laws of Ukraine, decrees of the President of Ukraine, resolutions of the Government); agreements on cooperation in the area of space industry were concluded with 24 countries of the world; National Center for Control and Testing of Space Vehicles with a powerful ground infrastructure was established; new launch vehicle control system was created and processed on the basis of a platform-free inertial navigation system, etc.

The industry has retained its human and intellectual potential, modern technology, experimental and industrial base. Close cooperation with the National Academy of Sciences of Ukraine allowed to create a unique space technology, which provided participation in international projects such as "Marine Start", "Ground Start", "Dnipro", "Antares", "Vega", International Space Station and in many scientific experiments. Since 1992, 140 launch vehicle of national production have been launched from 6 spaceports of the world with 370 spacecraft, commissioned by 25 countries of the world [Bratitsya, 2009].

\section{Concept for implementation of State policy in the area of space activities for the period up to 2032}

On March 30, 2011, the Cabinet of Ministers of Ukraine by its Order no. 238 approved the Concept for Realization of State Policy in the Area of Space Activity for the Period up to 2032 [Concept, 2011], which defines the 20-year-long space strategy of Ukraine. The purpose of the Concept is to increase the efficiency of use of space potential for solving urgent tasks of socioeconomic, ecological, cultural, informational and scientific and educational development of society, ensuring national security and protecting the geopolitical interests of the State.

The directions of the Concept's implementation are: 1) ensuring the development of space technologies and their integration into the real sector of the national economy and into the sphere of national security and defense; 2) obtaining new knowledge, raising scientific and technical potential of the State and educational level of its citizens; 3) improvement of rocket and space technology and techniques for its creation; 4) implementation of effective industrial policy and modernization of production; 5) commercialization of space activities; 6) deepening of international cooperation in the area of space activities.

The tasks should be resolved by improving mechanisms of State support and providing investment attractiveness of space activities as a result of: 1) satisfaction of social needs in 
remote sensing area as well as in the satellite navigation and telecommunications services; 2) expansion of the presence of Ukrainian enterprises on the global space market, providing access to space; 3) space research, applied research aimed at development of advanced prototypes of space engineering and advanced technologies, implementation of prestigious national projects as well as execution of scientific and educational programs; 4) acceleration of rocket and space engineering rate of growth and improvement of its the competitiveness; 5) broadening the international cooperation.

The concept is expected to be realized by 2032 in three stages. The first stage (2018 2022) provides for implementation of the State priority tasks, access to advanced technologies, technical re-equipment of enterprises, structural optimization of the industry at the enterprise level, creation of new national and industrial international cooperation.

At the second stage (2023 - 2027), the formation of the internal market of space information services, implementation of its own space projects through the use of expanded national and international industrial cooperation, a steady positive impact of space activities on the country's economy will take place; enterprises of the space industry are expected to become internationally competitive.

The third stage (2028-2032) includes implementation of breakthrough space technologies and projects with European and other key partners countries, sustainable innovation development of the space industry, direct positive impact on the innovation development of related industries of the country, strong positions in the world market.

The implementation of the Concept will enable the formation of an economically sustainable, competitive, diversified rocket and space industry, and for its successful implementation the Plan of measures on the implementation of the Concept was approved by the Cabinet of Ministers of Ukraine on January 25, 2012.

\section{Strategy for Space activity of Ukraine to 2022}

There is also the Strategy for Space Activity of Ukraine to 2022 (hereinafter referred to as the Strategy), approved by the Order of the State Space Agency of Ukraine no. 100 on May 21, 2015 [Strategy, 2015]. The Strategy is a guiding line for Ukraine for the next 7 years, the basis for developing a roadmap for the activities of the State Space Agency and the space industry. The need to develop the Strategy is due to the changes in political and economic situation in the country, new challenges faced by the space industry.

The Strategy determines the problems that need to be solved, the targets, the ways of its implementation, and contains a complex of priority measures aimed at ensuring the development of the space industry.

The purpose of the Strategy is to increase efficiency of space activities, to solve the urgent tasks of national security and defense, to realize the geopolitical interests of the State, to promote socio-economic, scientific and educational and ecological and cultural development of the society, to increase the prestige of Ukraine as a space State on the world arena, to transform the space industry of Ukraine into the catalyst for high-tech development of the national economy.

The Strategy clearly identifies the range of problems that need to be solved. They are: 1) discrepancy in the opportunities provided by modern space technologies, including information systems, and the state of their implementation in Ukraine for the needs of national security and defense, development of education and science, civil society, effective management and 
high-tech economy development; 2) absence of legislative motivational reasons for attracting investments in scientific and production spheres on the principles of public-private partnership and private entrepreneurship; 3) limited economic ties with the former traditional markets of goods and services involved in space activities; 4) low efficiency of economic activity of enterprises due to imperfect structure of space industry; 5) gaps on the technical and technological levels of the space industry, slow introduction of modern technologies of design, production, materials and components; 6) overwhelming majority of employees of the senior age group in leading enterprises and institutions, inconsistency between the parameters of space workers and modern social standards for space workers, the need to transfer experience and knowledge from older workers to young people.

The Strategy also proposes the ways to solve the above-mentioned problems, as well as the expected results of its implementation.

Unfortunately, although the Strategy involves important and necessary measures, many of them have been transferred from previous years due to lack of funding. According to the director of the Space Research Institute of the National Academy of Sciences of Ukraine and the National Space Agency of Ukraine Oleg Fedorov, the scope and regularity of works funding makes it impossible to perform a critical mass. And one of the signs of the current state of space industry is inability to develop and perform the proper space program. But if there is no such a program, there is no strategic vision of our role in space as well, and since the last Ukrainian satellite worked seven years ago, the current state of affairs should be assessed as a crisis [Prokopenko, 2018].

Volodymyr Babych emphasizes that in order to achieve sustainable economic development of the national economy and a decent level of competitiveness of the State economic system in the modern world, the improvement and implementation of the innovation-investment model of development is urgently needed, in which the formation of State innovation and investment policy system plays a key role [Babych, 2015]. We fully concur with the scientist, as the funding of the space industry was recently carried out as a residual. Thus, in 2014, 70 million UAH were put into the State budget of Ukraine for the execution of works on State target programs and State orders in the area of space industry [Law, 2014]; in 2019 this amount remained almost unchanged - UAH 78.5 million [Law, 2019]. As the mentioned Oleg Fedorov correctly observes, the current funding of the program in the amount of UAH 80 million is the budget of the research institute, not the space industry. Under such conditions, the need to attract public investment in the development of the national space industry is evident.

\section{Conclusions}

In this article we have reviewed the main regulatory acts of Ukraine that govern issues related to the implementation of space activities. In general, this branch is adjusted by a number of Laws of Ukraine, decrees of the President of Ukraine, resolutions of the Cabinet of Ministers of Ukraine, as well as the acts of the State Space Agency of Ukraine. Clearly, multilateral international treaties (the Treaty on Principles Governing the Activities of States for the Exploration and Use of Outer Space, including the Moon and Other Celestial Bodies of October 10, 1967, the Convention on Registration of Objects Launched into Outer Space of September 15, 1976, the Declaration on International Cooperation in the Exploration and Use of Outer Space for the benefit and in the interests of all States, with particular reference 
to the needs of developing countries of December 13, 1996 and many others), international agreements within the SAS, as well as a large number of bilateral agreements concluded between Ukraine and other countries of the world cannot be ignored.

Such an extensive system of regulatory acts managing the implementation of space activities shows the transformation of the space industry into one of the leading sectors of the Ukrainian economy. Ensuring the development of modern space technologies in Ukraine is an important factor determining the strategic position of the State in the world. Ukraine has the status of the space State due to the existence of powerful scientific and technological and intellectual potential, experience in the development of rocket and space technology and takes a proper place among high-tech States. During the years of independence, the regulatory framework for space activities has been created, the production of rocket and space equipment has been preserved, international commercial projects have been implemented, participation in international scientific projects has been provided.

At the same time, many problems still remain unresolved. In particular, the current state of space activity and existing mechanisms of its State regulation do not fully meet the urgent national tasks in the area of space activities. Thus, there is no effective mechanism for attracting investment in the space industry. Article 4 of the Law "On Space Activities" stipulates that one of the main principles of space activity in Ukraine is State support for commercialization of space activities and attraction of investments into the space industry of Ukraine. To accomplish this task, the Draft Law no. 9219 planned to introduce changes to Article 4 of the Law "On Entrepreneurship" that would enable non-State actors of entrepreneurial activity to do business in development, testing, production and operation of launch vehicles, which would mean the continuation of the course of Ukraine aimed at commercialization of space activities and attracting investment in the space industry. However, the Draft Law no. 9219, as it was already mentioned above, did not gain the required number of votes.

Secondly, there is a limited funding and insufficient State support for space activities in general. Indeed, funds for the development of this sector of the economy are reprogrammed to the State Budget of Ukraine as a residual; from year to year there is a reduction of financing of this industry. Of course, the State, which is currently in a state of war, is forced to allocate more money to maintain the country's defense capability and resolve other priority tasks. In the face of these events, the importance of attracting foreign investment for the development of space activities is of particular importance.

There are a number of other problems in Ukraine: the loss of a part of the terrestrial space infrastructure in the Autonomous Republic of Crimea; long delays with the implementation of structural changes in the space industry; absence of the internal market of space services, etc. Their solution is possible only with the development of a balanced national space program, which will be properly funded, envisaging the creation of a favorable climate for attracting foreign investment, conducting researches with foreign countries and participating in joint space programs.

\section{미] References}

Law Ukraine. About the State Budget of Ukraine for 2014. Approved by the Verkhovna Rada of Ukraine on January 16, 2014. https://zakon.rada.gov.ua/laws/show/719-18.

Law Ukraine. About the State Budget of Ukraine for 2019. Approved by the Verkhovna Rada of Ukraine on 28.02. 2019. https://zakon.rada.gov.ua/laws/show/2696-19. 
Babych, Volodymyr. Modern approaches to the formation of state innovation and investment policy. Biznesinform, № 3, 2015. pp. 117 - 122. http://www.business-inform.net/ export_pdf/business-inform-2015-3_0-pages-117_122.pdf

Bukvych, Anna. Public-Private Partnership in Ukraine: Will We Reform? Yurydychna Gazeta, on 13.12.2016. https:/www.pressreader.com/ukraine/yurydychna-gazeta/20161213/ page $/ 20$

Bratitsya, Leonid. Aerospace Science in Ukraine. Chronology of events. Ukraine is a space and aviation state. Image.U. №2, 2009. https://issuu.com/image.ua/docs/image.ua_2009.2

Drapailo, Yulian. On the new directions of economic-legal regulation (on the example of space activity). Current problems of State and Law, 2012. http://apdp.in.ua/v64/54.pdf

Concept for Realization of State Policy in the Area of Space Activity for the Period up to 2032. Approved by the Cabinet of Ministers of Ukraine on March 30, 2011. https://zakon. rada.gov.ua/laws/show/238-2011-\%D1\%80.

Concept of the National Target Scientific and Technical Space Program of Ukraine for 2018 2022 was adopted by the Order of the Cabinet of Ministers of Ukraine № 629-2018-p, on 05.09.2018. https://zakon.rada.gov.ua/laws/show/629-2018-\%D1\%80

Effective International Law. Moscow Independent Institute of International Law, 1997: 625 630.

LOI $n$ 2008-518 relative aux opérations spatiales. NOR: ESRX0700048L Version consolidée au 29 juillet 2019. https:/www.legifrance.gouv.fr/affichTexte. do? cidTexte=JORFTEXT000018931380

On Amending Certain Laws of Ukraine on Facilitating the Development of Space Activities and Involvement of Investments in the Space Industry of Ukraine. (the Draft Law of Ukraine of October 18, 2018), 2018. http://search.ligazakon.ua/1_doc2.nsf/link1/ JH74300A.html.

On Approval of the Plan of Action for Realization of the Concept for Realization of State Policy in the Area of Space Activity for the Period up to 2032. (Approved by the Cabinet of Ministers of Ukraine on January 25, 2012), 2012. https://zakon.rada.gov.ua/ laws/show/48-2012-\%D1\%80.

Law Ukraine. On Entrepreneurship on February 7, 1991. https://zakon.rada.gov.ua/laws/ show/698-12.

Law Ukraine. On Space Activities on November 15, 1996. https://zakon.rada.gov.ua/laws/ show $/ 502 / 96-\% \mathrm{D} 0 \% \mathrm{~B} 2 \% \mathrm{D} 1 \% 80$.

Law Ukraine. On State Support to Space Activities. on March 16, 2000. https://zakon.rada.gov. ua/laws/show/1559-14.

Law Belgiane. On the Activities of Launching, Flight Operation or Guidance of Space Objects on 17 September 2005. consolidated text as revised by the Law of 1 December 2013 (B.O.J. of 15 January 2014). https://www.belspo.be/belspo/space/doc/beLaw/Loi_ en.pdf

Prokopchuk, Stanislav. Ukrainian space: the flight is normal. Uryadovyy kuryer, 2019 https:// ukurier.gov.ua/uk/articles/ukrayinskij-kosmos-polit-normalnij/.

Prokopenko, Maria. About the New Philosophy of Space Research. Newspapers “Day”, №185186, 2018. https://day.kyiv.ua/uk/article/cuspilstvo/pro-novu-filosofiyu-kosmichnyhdoslidzhen.

Regulation on the State Space Agency of Ukraine. Approved by the Cabinet of Ministers Ukraine on May 14, 2015. https://zakon.rada.gov.ua/laws/show/281-2015-\%D0\%BF. 
Royal Decree implementing certain provisions of the Law on the activities of launching, flight operations and guidance of space objects. Approved by the Federal Public Service on September 17, 2005. https://download.esa.int/docs/ECSL/Belgium2.pdf

Space-Inform. Verkhovna Rada failed the law on the lifting of the ban on the operation of private space companies. http://space.com.ua/2019/05/17/rada-provalyla-zakon-proskasuvannya-zaborony-na-robotu-pryvatnyh-kosmichnyh-kompanij/

Strategy for Space Activity of Ukraine to 2022. Approved by the State Space Agency of Ukraine on May 21, 2015. https://zakon.rada.gov.ua/rada/show/v0100814-15

Yurydychna entsyklopediya: v 6 tomah. Y. Shemshuchenko (vidp. red.). Kyiv: Ukr. entsykl., 2002. T. 4. 